\title{
POLISH CONSUMERS' AWARENESS AND KNOWLEDGE ABOUT FUNCTIONAL FOOD
}

\section{POLSKI KONSUMENT NA RYNKU ŻYWNOŚCI FUNKCJONALNEJ - JEGO WIEDZA I OCZEKIWANIA}

\author{
Department of Gastronomy Science and Functional Foods, Poznan University of Life Sciences, Poland
}

\begin{abstract}
Streszczenie. W dobie wzrostu zachorowalności na choroby o podłożu cywilizacyjnym konsumenci stawiają coraz wyższe wymagania produktom spożywczym. Spowodowane to jest wzrostem świadomości konsumentów na temat możliwości stymulowania metabolizmu przez określone składniki żywności. Odpowiedzią branży spożywczej na to zapotrzebowanie jest żywność funkcjonalna. Żywność funkcjonalna ma na celu poprawę aktywności organizmu człowieka poprzez poprawę procesów metabolicznych lub fizjologicznych. Zalecana zatem jest dla wzmacniania określonych funkcji organizmu lub w celu obniżenia zachorowalności na schorzenia o podłożu cywilizacyjnym. Celem przeprowadzonych badań była ocena stanu wiedzy polskich konsumentów na temat żywności funkcjonalnej, jaki mają do niej stosunek oraz zbadanie, czy grupa docelowa spożywa produkty należące do żywności funkcjonalnej. Badania ankietowe przeprowadzono w grupie 241 pracowników biurowych. Badano poziom wiedzy, znajomość oraz opinię respondentów na temat wpływu żywności funkcjonalnej na organizm człowieka, stosując elektroniczny formularz ankietowy. Zaobserwowano, że respondenci posiadali wybiórczą wiedzę na temat właściwości prozdrowotnych produktów należących do żywności funkcjonalnej, co podkreślali w swoich odpowiedziach. Stan wiedzy ankietowanych wpływał również na wymagania stawiane producentom tego rodzaju żywności. W świetle uzyskanych wyników badań istotna wydaje się kontynuacja edukacji społeczeństwa w zakresie żywności funkcjonalnej.
\end{abstract}

Key words: functional food properties, consumers knowledge, health-promoting effects, office staff.

Słowa kluczowe: właściwości żywności funkcjonalnej, poziom wiedzy konsumentów, działanie prozdrowotne, pracownicy biurowi.

\section{INTRODUCTION}

The concept of functional food is relatively a new term. However, due to the origin - Far Eastern philosophy, which indicates strong correlation between food and medicine, in Far East countries functional food has been known for ages. Japan was a precursor in the design, manufacturing and consumption of this type of food. Already in the 80 s of the $X X^{\text {th }}$ century, there were research on pro-healthy food products carried out. Also Japan as a first

Corresponding author - Adres do korespondencji: Monika Przeor, Department of Gastronomy Science and Functional Foods, Poznan University of Life Sciences, Wojska Polskiego 31, 60-624 Poznań, Poland, e-mail: monika.przeor@up.poznan.pl 
country defined an assortment of Foods for Specified Health Use (FOSHU), which represents one of the first legal regulations in this area (Warfel et al. 2007). In Europe and USA there are many names and definitions that describe the nature, features and functional properties of food products. Therefore, the European Union approved a definition formed during the research program named FUFOSE (Functional Food Science in Europe), which states that 'food can be considered as functional if there are proven its beneficial effects on one or more organism functions over nutritional effect, like improving the health, well-being and/or reducing risk of diseases'. This kind of food has to resemble a conventional food and has beneficial effects in amounts that are expected to be normally consumed in the diet - are not tablets or capsules, but a part of normal diet (Krygier and Florowska 2008).

Such precise determination of functional food products is necessary and appropriate from the nutritionists point of view. However, public education, and so dissemination of functional food products may prove challenging, and success in this venture - to be a milestone. It may turn out that consumers accustomed to the traditional diet, will not be convinced to innovative food products. Naturally, this attitude depend on the socio-economic and biological factors (Steinka 2009).

Food manufacturing is one the most fundamental and lasting throughout the times. It evolves with socio-economic changes and every appearance of new type of food product can change it in various directions. In Japan food with health-promoting properties widely exists for many years. Despite that fact, its appearance in Poland is a breakthrough. How great change it is indicates value of 15 billion dollars - estimated value of the European market of functional food in 2006 (Siró et al. 2008). On the market we can already find functional food products, such as bakery products, diary products, sweets, chrisps, beverages etc. (Kobus-Cisowska et al. 2016a, b; Przeor and Flaczyk 2016). In accordance to above, consumer's attitude to health-promoting food should be identified.

It seems that polish people greatly appreciate conventional foods as well as culinary traditions, and are interested in new aspects of consumption and food technology simultaneously. For nutritionists, it is a adequate background for interest Poles in functional food. Significant expansion of the range of such food products should be based on previous monitoring of the behaviors of various social groups. It can be also dependent on education, health status, age, sex, financial status, lifestyle etc. Considering above, the aim of the study was to determine the level of knowledge and interest in functional food products among white-collar workers. That group of consumers seems to be well educated, but sitting most of the time during workday.

\section{MATERIAL AND METHODS}

The study was conducted with electronic form questionnaire in April and May, 2014 in group of 241 people, white-collar workers who declared to participate in research. There were 241 questionnaires collected. Questionnaires in electronic form guaranteed correct filling. The research tool was the original questionnaire containing 26 questions. First part of questionnaire was related to the approach of respondents to pro-healthy food products and state of their knowledge about functional food. The second part constituted personal characteristic of respondent. 
In questions related to state of knowledge and attitude of respondents to food there was five-point Likert's scale used. The scale consists of odd number of possible answers and evaluates it from 'complete agreement' to 'complete disagreement', central value expresses 'neutrality/ no opinion'. The scale also evaluates the strength of endorsement for given answer. Answers: 'definitely agree', 'rather agree', 'hard to say', 'rather disagree', 'totally disagree' were used as points of scale (Wasilewska 2008). Results were analyzed statistically in Statistica 10 software. Spearman Rank Correlation for selected relations between groups was used as statistical test.

\section{RESULTS AND DISCUSSION}

In the Table 1 the characteristic of examined group of people according to their responses is given. In the study 241 white-collar workers were examined, including 119 women (49.4\%) and 122 men (50.6\%). Definitely most of them came from big city (57.7\%). All male respondents came from cities or big cities. $7.9 \%$ of respondents came from towns, only female. Considering the age of respondents, young people under 39 years old predominated $(70.5 \%)$. Over $90 \%$ of respondents declared higher education $(91.2 \%)$, all men in it. It is known, that fundamental determinant of food selection is consumer financial capabilities, and that is the reason of question about self-assessment of material situation in questionnaire. It was observed that almost half of respondents defined their situation as 'good' (48.5\%), $36.5 \%$ as 'good enough' and $14.9 \%$ as 'very good'. The group of respondents was diverse in terms of household population. $51.8 \%$ of them lived alone or in a couple. In three- or four-person families lived $43.6 \%$ of respondents, and just one in twenty had five- or six-person household. Thus, it can be concluded that average white-collar worker was young, well educated person with good financial situation, who lived in big city in 3-4 - person household. This created surveyed respondent's profile can be useful in analysing questionnaires.

Second part of the survey was about consumers knowledge about functional food. In the study white-collar workers suggested the relationship between the functional food intake and health - statistically significant correlation (Table 2). Significant amount of respondents believe that pro-healthy food products (answers: definitely yes or rather yes) have a positive effect on health $(95.1 \%)$, are carefully controlled $(78.1 \%)$, naturally contain a lot of vitamins and minerals (90.2\%) or another beneficial ingredients $(70.7 \%)$. A similar level of knowledge of Italian consumers was presented in Annunziata and Vecchio (2011) research, however their respondends were not able to define functional food clearly.

Previous studies of Polish consumers indicated a knowledge of such food by only $4 \%$ of respondents. For comparison, this percentage among Belgians stood at the level of $49 \%$ (Krygier 2007). On the one hand, observed effect may be related with slow but gradual presence of functional food products in retail. On the other hand, there is increasing transmission of information through the media and 'healthy diet' trends in modern society. In this case, the desire to try new products and friends opinion are proved to be the main factors driving the purchase. Respondent opinions were ambiguous when asked if healthpromoting food products have extra functions (Table 2). 
Table 1. Characteristic of the group of respondents

Tabela 1. Charakterystyka grupy ankietowanych

\begin{tabular}{|c|c|c|c|c|c|c|}
\hline & \multicolumn{2}{|c|}{ Men - Mężczyźni } & \multicolumn{2}{|c|}{ Women - Kobiety } & \multicolumn{2}{|c|}{ All - Łącznie } \\
\hline & \multicolumn{4}{|c|}{$\begin{array}{l}\text { amount / \% of group } \\
\text { liczba / \% grupy }\end{array}$} & \multicolumn{2}{|c|}{$\begin{array}{l}\text { amount } / \% \text { of all } \\
\text { liczba } / \% \text { ogółem }\end{array}$} \\
\hline Age - Wiek & \multicolumn{2}{|c|}{$\%$} & \multicolumn{2}{|c|}{$\%$} & \multicolumn{2}{|c|}{$\%$} \\
\hline$\leq 29$ years - lat & 39 & 32.0 & 50 & 42.1 & 89 & 36.9 \\
\hline $30-39$ years - lat & 50 & 41.0 & 31 & 26.0 & 81 & 33.6 \\
\hline $40-49$ years - lat & 22 & 18.0 & 25 & 21.0 & 47 & 19.5 \\
\hline$\geq 50$ years - lat & 11 & 9.0 & 13 & 10.9 & 24 & 10.0 \\
\hline \multicolumn{7}{|l|}{ Education - Wykształcenie } \\
\hline primary - podstawowe/zawodowe & 0 & 0.0 & 0 & 0.0 & 0 & 0.0 \\
\hline secondary - średnie & 0 & 0.0 & 19 & 16.0 & 19 & 7.9 \\
\hline university - wyższe & 122 & 100.0 & 100 & 84.0 & 222 & 92.1 \\
\hline \multicolumn{7}{|l|}{ Domicile - Zamieszkanie } \\
\hline village - wieś & 0 & 0.0 & 0 & 0.0 & 0 & 0.0 \\
\hline town - miasto $<30$ tys. & 0 & 0.0 & 19 & 16.0 & 19 & 7.9 \\
\hline city - miasto $30-100$ tys. & 39 & 32.0 & 44 & 37.0 & 83 & 34.4 \\
\hline big city - miasto $>100$ tys. & 83 & 68.0 & 56 & 47.0 & 139 & 57.7 \\
\hline \multicolumn{7}{|l|}{ Financial status - Sytuacja materialna } \\
\hline very good - bardzo dobra & 17 & 13.9 & 19 & 16.0 & 36 & 14.9 \\
\hline good - dobra & 55 & 45.1 & 62 & 52.1 & 117 & 48.5 \\
\hline good enough - wystarczająca & 50 & 41.0 & 38 & 31.9 & 88 & 36.5 \\
\hline $\mathrm{bad}-\mathrm{zła}$ & 0 & 0.0 & 0 & 0.0 & 0 & 0.0 \\
\hline \multicolumn{7}{|l|}{ Household population } \\
\hline \multicolumn{7}{|l|}{ Liczba osób w gospodarstwie domowym } \\
\hline 1-2 people - osoby & 50 & 41.0 & 75 & 63.1 & 125 & 51.8 \\
\hline 3 people - osoby & 28 & 23.0 & 31 & 26.0 & 59 & 24.5 \\
\hline 4 people - osoby & 33 & 27.0 & 13 & 10.9 & 46 & 19.1 \\
\hline 5-6 people - osób & 11 & 9.0 & 0 & 0.0 & 11 & 4.6 \\
\hline >6 people - osób & 0 & 0.0 & 0 & 0.0 & 0 & 0.0 \\
\hline
\end{tabular}


Table 2. Health-promoting food in respondents' opinion

Tabela 2. Stosunek respondentów do żywności prozdrowotne

In your opinion pro-healthy food is...

Answers - Odpowiedzi [\%]

Pani(-a) zdaniem żywność prozdrowotna

to (żywność)...

\begin{tabular}{|c|c|c|c|c|c|}
\hline \multirow{2}{*}{$\begin{array}{l}\text { In your opinion pro-healthy food is... } \\
\text { Pani(-a) zdaniem żywność prozdrowotna } \\
\text { to (żywność)... }\end{array}$} & \multicolumn{5}{|c|}{ Answers - Odpowiedzı [\%] } \\
\hline & $\begin{array}{l}\text { definitely yes } \\
\text { zdecydowanie tak }\end{array}$ & $\begin{array}{l}\text { rather yes } \\
\text { raczej tak }\end{array}$ & $\begin{array}{l}\text { difficult to say } \\
\text { trudno powiedzieć }\end{array}$ & $\begin{array}{l}\text { rather no } \\
\text { raczej nie }\end{array}$ & $\begin{array}{l}\text { definitely no } \\
\text { zdecydowanie nie }\end{array}$ \\
\hline $\begin{array}{l}\text {...with higher nutritional value } \\
\text {...o zwiększonej wartości odżywczej }\end{array}$ & 26.8 & 24.4 & 26.8 & 14.6 & 7.3 \\
\hline $\begin{array}{l}\text {...with positive effect on health } \\
\text {...o pozytywnym wpływie na zdrowie i samopoczucie }\end{array}$ & 78.0 & 17.1 & 2.4 & 2.4 & 0.0 \\
\hline $\begin{array}{l}\text {...easy and quick to prepare } \\
\text {...łatwa i szybka w przygotowaniu }\end{array}$ & 2.4 & 19.5 & 36.6 & 26.8 & 14.6 \\
\hline $\begin{array}{l}\text {...ready to eat without cooking } \\
\text {...gotowa do spożycia bez obróbki cieplnej }\end{array}$ & 9.8 & 19.5 & 34.1 & 22.0 & 14.6 \\
\hline $\begin{array}{l}\text {...carefully controlled } \\
\text {....która jest starannie kontrolowana }\end{array}$ & 48.8 & 29.3 & 19.5 & 2.4 & 0.0 \\
\hline $\begin{array}{l}\text {...enriched with vitamins/ minerals } \\
\text {...dodatkowo wzbogacona w witaminy i składniki mineralne }\end{array}$ & 36.6 & 22.0 & 12.2 & 17.1 & 12.2 \\
\hline $\begin{array}{l}\text {...naturally contains lot of vitamins and minerals } \\
\text {...naturalnie zawierająca dużo witamin i składników mineralnych }\end{array}$ & 63.4 & 26.8 & 7.3 & 2.4 & 0.0 \\
\hline $\begin{array}{l}\text {...supports the organism function } \\
\text {...spełniająca dodatkowe funkcje dla organizmu }\end{array}$ & 34.1 & 41.5 & 19.5 & 2.4 & 2.4 \\
\hline $\begin{array}{l}\text {...long-life } \\
\text {...o długim terminie przydatności }\end{array}$ & 0.0 & 4.9 & 31.7 & 26.8 & 36.6 \\
\hline $\begin{array}{l}\text {...more expensive than regular food } \\
\text {...droższa od zwykłych produktów }\end{array}$ & 24.4 & 41.5 & 24.4 & 9.8 & 0.0 \\
\hline $\begin{array}{l}\text {...the same as eco food } \\
\text {...to samo co żywność ekologiczna }\end{array}$ & 2.4 & 7.3 & 39.0 & 29.3 & 22.0 \\
\hline $\begin{array}{l}\text {...with beneficial ingredients ex. vitamins, minerals } \\
\text {...zawierająca korzystne składniki - inne niż witaminy i składniki } \\
\text { mineralne }\end{array}$ & 26.8 & 43.9 & 26.8 & 2.4 & 0.0 \\
\hline
\end{tabular}


However, relatively substantial lack of knowledge was reported after analyzing answers about practical recommendations to functional food preparation. White-collar workers had a problem with determining whether such products are easy-to-prepare or pretreatment before eating is required. It turns out, this attitude may result from confusion while shopping and difficulties in recognition of functional food in the store. Thus it is difficult to specify functional food intake precisely, if respondents are not able to identify them. A similar trend with functional bakery products was observed by another researchers (Kowalska et al. 2012). Judging by answers obtained from polish white-collar workers it can be stated that knowledge about functional food is not enough.

Among Polish white-collar workers more than 1/3 declared lack of knowledge of functional food definition, $39 \%$ of them heard about but do not know it, and $22 \%$ completely did not know functional food products (Table 3). Previous research showed there are countries like Uruguay where functional food is seen as 'healthier' than conventional, especially by the elderly (Ares et al. 2008). However, there are also barriers to general acceptance of these foods. Consumers think that functional food products are tasteless, are unnatural and expensive (Urala and Lahteenmaki 2004). In our studies, a great number of white-collar workers $(65.9 \%)$ thought the same about products price. Despite this, $78.4 \%$ of respondents declared they would pay up to $30 \%$ more for functional food products. Only few $(9.8 \%)$ did not perceive these products as expensive. There was observed negative correlation between age and willingness to buying products if are more expensive. $38.3 \%$ of $40-49$-year-old respondents refused buying this kind of products. 'The artificiality' may be determined by shelf life. White-collar workers (63.4\%) 'rather' or 'definitely did not' characterized functional food as having high durability. A similar number of respondents $(61.3 \%)$ did not treat it as eco food.

Consumer familiarity and knowledge about each new food product in formed in two ways: by incoming information, as well as through their own experience and decisions taken during shopping. In case of food products, this aspect is extended to positive and negative effect on human health. This consumer awareness was shown in these studies. It was shown that basic information point about product for consumers, regardless of age, is reliable label containing ingredients and nutritional value (Flaczyk et al. 2013). European law obliges food producers to prepare 'clear and understandable labels in order to assist consumers who want make better-informed food and dietary choices' (Rozporządzenie Parlamentu Europejskiego i Rady (UE) nr 1169/2011 z dnia 25 października 2011 r.). In our studies, $24.4 \%$ of white-collar workers declared that 'always' pay attention to the nutritional value and basic composition, and $63.4 \%$ of them - 'sometimes' (Table 3 ). Considering the above, amount of respondents (63.4\%) who support placing a special nutrition declaration on functional food products seems to be predictable. Moreover, these respondents suggest that functional food should be placed at special place in the store, to distinguish it from conventional food products. Such an attitude stems from declared, in their opinion, insufficient information consumers had about pro-healthy properties of functional food. 
Table 3. Respondents' decisions about health-promoting food

Tabela 3. Decyzje podejmowane przez respondentów ws. żywności prozdrowotnej

\begin{tabular}{|c|c|c|c|c|c|}
\hline \multirow{2}{*}{$\begin{array}{l}\text { Questions and available answers } \\
\text { Pytania i możliwe odpowiedzi } \\
\text { [amount / \% of group - liczba / \% grupy] }\end{array}$} & \multicolumn{4}{|c|}{ Age - Wiek respondentów } & \multirow{2}{*}{ All - Ogółem } \\
\hline & $\leq 29$ years - lat & $30-39$ years - lat & $40-49$ years - lat & $\geq 50$ years - lat & \\
\hline
\end{tabular}

Do you pay attention to composition and nutritional value of food products while shopping?

Czy wybierając produkty do zakupu i spożycia, zwraca Pan(-i) uwagę na skład i wartość odżywczą?

\begin{tabular}{|c|c|c|c|c|c|c|c|c|c|c|}
\hline Yes, always - Tak, zawsze & 30 & 33.7 & 12 & 14.8 & 12 & 25.6 & 6 & 25.0 & 60 & 24.9 \\
\hline Yes, sometimes - Tak, czasami & 53 & 59.6 & 52 & 64.2 & 30 & 63.8 & 18 & 75.0 & 153 & 63.5 \\
\hline No, never - Nie, nigdy & 6 & 6.7 & 17 & 21.0 & 5 & 10.6 & 0 & 0.0 & 28 & 11.6 \\
\hline \multicolumn{11}{|l|}{$\begin{array}{l}\text { Do you know the term „health-promoting food”? } \\
\text { Czy zna Pan(-i) znaczenie pojęcia „żywność prozdrowotna”? }\end{array}$} \\
\hline I know - Tak, znam & 41 & 46.1 & 29 & 35.8 & 6 & 12.8 & 18 & 75.0 & 94 & 39.0 \\
\hline $\begin{array}{l}\text { Heard but not under stand - Słyszałem(-am), ale nie znam } \\
\text { tego pojęcia }\end{array}$ & 30 & 33.7 & 23 & 28.4 & 35 & 74.4 & 6 & 25.0 & 94 & 39.0 \\
\hline Rather not Heard - Raczej nie znam & 18 & 20.2 & 29 & 35.8 & 0 & 0.0 & 0 & 0.0 & 47 & 19.5 \\
\hline Never Heard - Nigdy nie słyszałem(-am) & 0 & 0.0 & 0 & 0.0 & 6 & 12.8 & 0 & 0.0 & 6 & 2.5 \\
\hline
\end{tabular}

Never Heard - Nigdy nie słyszałem(-am)

Do you eat health-promoting food?

Czy spożywa Pan(-i) produkty zaliczane do grupy żywności prozdrowotnej?

\begin{tabular}{|c|c|c|c|c|c|c|c|c|c|c|}
\hline Yes - Tak & 53 & 59.6 & 29 & 35.8 & 24 & 51.1 & 12 & 50.0 & 118 & 48.9 \\
\hline $\mathrm{No}-\mathrm{Nie}$ & 0 & 0.0 & 12 & 14.8 & 0 & 0.0 & 6 & 25.0 & 18 & 7.6 \\
\hline Don't know - Nie wiem, jakie są to produkty & 36 & 40.4 & 40 & 49.4 & 25 & 48.9 & 5 & 25.0 & 107 & 44.5 \\
\hline \multicolumn{11}{|l|}{$\begin{array}{l}\text { What could convince you to buy this food? } \\
\text { Co skłoniłoby Pana(-nią) do zakupu tej żywności? }\end{array}$} \\
\hline Want to try - Chęć spróbowania & 80 & & 43 & & 39 & & 24 & & - & \\
\hline Medical recommendation - Zalecenie lekarza & 22 & & 20 & & 5 & & 12 & & - & \\
\hline Friends opinion - Opinia znajomych & 83 & & 40 & & 25 & & 6 & & - & \\
\hline Promotion - Reklama & 7 & & 11 & & 0 & & 0 & & - & \\
\hline Discount - Promocja & 6 & & 4 & & 0 & & 0 & & - & \\
\hline Nothing - Nic by mnie nie skłoniło & 0 & & 5 & & 0 & & 0 & & - & \\
\hline
\end{tabular}


Table 3. Respondents' decisions about health-promoting food (cont.)

Tabela 3.Decyzje podejmowane przez respondentów ws. żywności prozdrowotnej (cd.)

\begin{tabular}{|c|c|c|c|c|c|}
\hline \multirow{2}{*}{$\begin{array}{l}\text { Questions and available answers } \\
\text { Pytania i możliwe odpowiedzi } \\
\text { [amount / \% of group- liczba / \% grupy] }\end{array}$} & \multicolumn{4}{|c|}{ Age - Wiek respondentów } & \multirow[b]{2}{*}{ All - Ogółem } \\
\hline & $\leq 29$ years - lat & 30-39 years - lat & $40-49$ years - lat & $\geq 50$ years - lat & \\
\hline
\end{tabular}

Are consumers informed enough about health promoting food?

Czy uważa Pan(-i), że konsumenci są wystarczająco dobrze poinformowani na temat żywności o działaniu prozdrowotnym?

\begin{tabular}{|c|c|c|c|c|c|c|c|c|c|c|}
\hline Yes - Tak & 0 & 0.0 & 6 & 7.4 & 0 & 0.0 & 0 & 0.0 & 6 & 2.5 \\
\hline No - Nie & 89 & 100.0 & 52 & 64.2 & 41 & 87.2 & 18 & 75.0 & 200 & 83.0 \\
\hline Don't know - Nie mam zdania & 0 & 0.0 & 23 & 28.4 & 6 & 12.8 & 6 & 25.0 & 35 & 14.5 \\
\hline
\end{tabular}

Should the health-promoting food be marked with special label?

Czy uważa Pan(-i), że żywność prozdrowotna powinna być znakowana specjalnymi deklaracjami żywieniowo- zdrowotnymi?

\begin{tabular}{|c|c|c|c|c|c|c|c|c|c|c|}
\hline Yes - Tak & 60 & 67.4 & 40 & 49.3 & 24 & 51.1 & 24 & 100.0 & 148 & 61.4 \\
\hline $\mathrm{No}-\mathrm{Nie}$ & 29 & 32.6 & 35 & 43.2 & 11 & 23.4 & 0 & 0.0 & 75 & 31.1 \\
\hline Don't know - Nie mam zdania & 0 & 0.0 & 6 & 7.5 & 12 & 25.5 & 0 & 0.0 & 18 & 7.5 \\
\hline
\end{tabular}

Should health-promoting food lay on a special place in the store?

Czy uważa Pan(-i), że żywność prozdrowotna powinna mieć swoje specjalne miejsce w sklepie?

\begin{tabular}{|c|c|c|c|c|c|c|c|c|c|c|}
\hline Yes - Tak & 60 & 67.4 & 40 & 49.3 & 24 & 51.1 & 24 & 100.0 & 148 & 61.4 \\
\hline No - Nie & 29 & 32.6 & 35 & 43.2 & 11 & 23.4 & 0 & 0.0 & 75 & 31.1 \\
\hline Don't know - Nie mam zdania & 0 & 0.0 & 6 & 7.5 & 12 & 25.5 & 0 & 0.0 & 18 & 7.5 \\
\hline
\end{tabular}

Would you pay more for health-promoting food than traditional?

Był(-a)by Pan(-i) skłonny(-a)zapłacić więcej za żywność prozdrowotną niż za porównywalny produkt tradycyjny?

\begin{tabular}{|c|c|c|c|c|c|c|c|c|c|c|}
\hline $\mathrm{No}-\mathrm{Nie}$ & 6 & 6.7 & 17 & 21.0 & 18 & 38.3 & 6 & 25.0 & 47 & 19.5 \\
\hline Yes $<10 \%$ more - Tak, do $10 \%$ więcej & 36 & 40.4 & 40 & 49.3 & 24 & 51.1 & 12 & 50.0 & 112 & 46.5 \\
\hline Yes $<30 \%$ more - Tak, do $30 \%$ więcej & 42 & 47.2 & 24 & 29.7 & 5 & 10.6 & 6 & 25.0 & 77 & 31.9 \\
\hline Yes $<50 \%$ more - Tak, do $50 \%$ więcej & 5 & 5.7 & 0 & 0.0 & 0 & 0.0 & 0 & 0.0 & 5 & 2.1 \\
\hline Yes $<100 \%$ more - Tak, do $100 \%$ więcej & 0 & 0.0 & 0 & 0.0 & 0 & 0.0 & 0 & 0.0 & 0 & 0.0 \\
\hline
\end{tabular}


For months, there has been dynamic development in Polish food technology observed. It allows the creation of innovative food products focused on nutritional quality. The appearance of functional foods in the Polish market is progressing consistently as well as consumers attitudes. Growing interest in healthy lifestyle, and also in pro-healthy nutrition, gives technologists the opportunity to give new features to the food products (preventive and even therapeutic properties) by enriching them with natural ingredients with proven biological activity. As it turns out, consumers are wary in assessing and trusting such new products. The conducted research showed that white-collar workers knowledge was incomplete, and answers provided in the questionnaire often were inharmonious. Respondent fears to innovative functional food products appearing on the store shelves were apparently declared in the survey. The thorough analysis of collected questionnaires, as well as other papers (Sadowska and Bruszkowska 2016) indicate that reliable nutritional education is required. It can certainly raise confidence in health-promoting foods.

\section{CONCLUSIONS}

Conducted studies helped to specify the state of knowledge of polish white-collar workers, mainly working in big cities, about functional food products and its daily use. This kind of food could be successfully used by them to improve health status, which can be impaired due to the specificity of work. In the study it was found that:

1. Consumers are aware of the impact of diet on human health, including the benefits that functional food causes.

2. Respondents were not able to describe the functional food clearly, that proves their incomplete knowledge about these products and consequences of consumption.

3. Lack of information in the interviewed group of white-collar workers results in high demands they put on manufacturers for special labels and positions in stores. It is important to create clear label with all highlighted pro-healthy features.

4. Nutritional education, eg. with using public campaigns, clear labels, lectures in workplace, recommendations from medical doctors etc., is necessary in order to improve consumer confidence in health-promoting food.

\section{REFERENCES}

Annunziata A., Vecchio R. 2011. Functional foods development in the European market: A consumer perspective. J. Funct. Foods. 3, 223-228.

Ares G., Giménez A., Gámbaro A. 2008. Influence of nutritional knowledge on perceived healthiness and willingness to try functional foods. Appetite 51, 663-668.

Flaczyk E., Charzyńska A., Przeor M., Korczak J. 2013. Akceptacja produktów żywnościowych na podstawie informacji na opakowaniach $w$ zależności od wieku, wiedzy żywieniowej i płci konsumentów [Acceptance of food products on the basis of label information depending on age, gender and nutrition knowledge of consumers]. Nauki Inż. Technol. 4(11), 20-38. [in Polish]

Kobus-Cisowska J., Flaczyk E., Przeor M., Kmiecik D., Hęś M., Szymandera-Buszka K. 2016a. Możliwości wykorzystania preparatów z liści morwy jako składników mlecznych napojów fermentowanych, w: Bioprodukty - pozyskiwanie, właściwości i zastosowanie w produkcji żywności. Red. G. Lewandowicz, J. Le Thanh-Blicharz. Poznań, Wydaw. Uniw. Przyr. Pozn., 30-37. ISBN 978-83-7160-835-3. [in Polish] 
Kobus-Cisowska J., Kmiecik D., Flaczyk E., Przeor M., Kulczyński B. 2016b. Projekt nowego produktu z dodatkiem nasion chia (Salvia hispanica L.) jako składnika żywności bioaktywnej, w: Innowacyjne rozwiązania w technologii żywności i żywieniu człowieka. Red. T. Tarko, I. Drożdż, D. Najgebauer-Lejko, A. Duda-Chodak. Kraków, Wydaw. Oddział Małopolski Polskiego Towarzystwa Technologów Żywności, 23-31. ISBN 978-83-937001-8-9. [in Polish]

Kowalska H., Marzec A., Mucha M. 2012. Ocena sensoryczna wybranych rodzajów pieczywa funkcjonalnego oraz preferencje pieczywa wśród konsumentów [Sensory evaluation of some types of bread and functional consumer preferences among the bread]. Zesz. Probl. Post. Nauk Rol. 571, 67-78. [in Polish]

Krygier K. 2007. Functional foods in Poland, in: Proceedings of the 4th international FFNet meeting on functional foods. Budapest, [b.w.].

Krygier K., Florowska A. 2008. Żywność funkcjonalna obecnie i w przyszłości [Functional food present and in the future]. Przem. Spoż. 5, 2-6. [in Polish]

Przeor M., Flaczyk E. 2016. Antioxidant properties of paratha type flat bread enriched with white mulberry leaf extract. Indian J. Trad. Knowl. 15(2), 237-244.

Rozporządzenie Parlamentu Europejskiego i Rady (UE) nr 1169/2011 z dnia 25 października 2011 r. w sprawie przekazywania konsumentom informacji na temat żywności, http://eurlex.europa.eu/legal-content/EN/TXT/?uri=CELEX:32011R116922.11.2011, access: 20.02.2018

Sadowska J., Bruszkowska M. 2016. Estimation of dietary supplements intake in a selected group of women over 50 and the risk assessment of interactions between the ingredients of dietary supplements and drugs. Rocz. Państw. Zakł. Hig. 67(4), 391-397.

Siro I., Kapolna E., Kapolna B., Lugasi A. 2008. Functional food. Product development, marketing and consumer acceptance - a review. Appetite 51, 456-467.

Steinka I. 2009. Akceptacja żywności niekonwencjonalnej przez młodych konsumentów [Acceptance of unconventional food for young consumers]. Żywn. Nauka Technol. Jakość 4(65), 218-226. [in Polish]

Urala N., Lähteenmäki L. 2004. Attitudes behind consumers' willingness to use functional foods. Food Qual. Prefer. 15, 793-803.

Warfel K., Aso Y., Gee D.L. 2007. Regulation of functional foods in Japan: Foods for Specialized Health Uses (FOSHU). J. Am. Dietetic Assoc. 107(8), Suppl. A34.

Wasilewska E. 2008. Statystyka opisowa nie tylko dla socjologów. Warszawa, Wydaw. SGGW. 25. [in Polish]

\begin{abstract}
Nowadays, we observe an increase in the incidence of lifestyle diseases. Consumers expect higher quality as well as additional features in food products. It is an effect of increasing awareness about the possibility of regulation of metabolism by food nutrients. Food industry created functional food as a response to societal demands. Originally, functional food has appeared in Japan, and there is still the most extensive range of this kind of food. In Europe it is also well known for technologists and nutritionists. However, it seems to be unexplored by common consumers. Functional food aims to improve the activity of human organism by improving its metabolism and physiological processes. Therefore, functional food intake is recommended for strengthening of certain body functions and for reducing the incidence of lifestyle diseases. The aim of the study was to evaluate the state of knowledge of Polish consumers about functional food, their interest in it and about consumption. The state of knowledge, opinion about functional food products properties and its effects on human body, were conducted with electronic survey. It was observed that the most of the respondents did not have adequate knowledge about functional food. Nutritional education is needed.
\end{abstract}

The research were supported by Department of Gastronomy Science and Functional Foods, Poznan University of Life Sciences. 